\title{
ART AND AUTOBIOGRAPHY: A STUDY OF THE SELF IN LITERATURE
}

\author{
Dr. Min Pun (Nepal)
}

\begin{abstract}
In this paper, I have attempted to apply critical approaches of William C. Spengemann to study Oscar Wilde's Salomé as an autobiographical work that involves a set of assumptions such as biographical information about the author and information about the work's genesis, which should be given the secondary importance. Instead of the idea of defining autobiography as self-written biography, it is necessary to understand the ways in which different autobiographers write in different forms and at different times. So the main purpose of this paper is to explore the self in literature, i.e. Wilde's Salomé. Essentially, how can a piece of literary work be considered as an autobiography that has been practiced in response to shifting ideas about the nature of the self?
\end{abstract}

KEYWORDS: Autobiography; the self; art; beauty; art for art's sake; critics

\section{INTRODUCTION}

The autobiographical genre is a key to self-realization. Wilde’s Salomé like any artistic creation represents both of his private and public life, its creator, which in turn facilitates a different kind of fulfillment for the writer himself and the reader. Genre practice, therefore, can be related to the self and to combinations that relate constituents of autobiography.

Autobiography reflects one's fears and problems that there is a common bond of humanity; it makes us to understand human emotions, successes and failures, thoughts and dreams. Immediately a number of questions arise: What is interesting to his/her contemporaries and to posterity if anyone is interested in the background details of a life behind the public printed record? What will be equally worthy in another age? Can one write of his work and experience with disappointments and satisfactions objectively? Is the main objective of the autobiography is to make the autobiographer a writer or a scientist?

Such questions spring to mind in preparing to delineate the ideas, events, and people in a life that is largely past. The objective facts are available elsewhere. What is not so easy to determine and is known only to the writer are matters of personal evaluation. Such as, the choice points in one's career, the way one's teachers and colleagues have affected him/her, and one's aspirations and goals. But it is such personal matters that the individual is revealed.

The problem of self-knowledge posited by autobiography in terms of the poetic form applies to Salomé. In this, Wilde wants his play to answer the question that 


\section{Crossing the Border: International Journal of Interdisciplinary Studies}

should deal with anyone who wants to know the self about himself and to portray his life as an example of that self.

As a result, the reading of Wilde's Salomé combines the method and moves of several autobiographies in order to throw light on the elements of it. A survey in autobiographical interpretation in its variety will cast similar light on Spengemann's complex approach to the study of literature such as autobiography.

\section{WHAT IS AUTOBIOGRAPHY?}

The term 'autobiography' is variously defined. Most definitions reveal a significant pattern: an increasing acceptance of the idea that autobiography employs symbolic as well as biographical materials. Typically, a piece of autobiography is often defined as,

a life narrative written by the author himself, a definition which can be held to include such other forms of literary self-revelation as memoirs, journals, diaries and letters. All these forms are closely related and often shade into each other; they can therefore be conveniently discussed in one article. 'What is autobiography?' asked George Borrow. 'Is it a merely record of the incidents or a man's life or is it a picture of the man himself-his character, his soul?' (Collier's Encyclopedia, 1957, pp. 143-144)

Here, a distinction is made between factual narrative and the confession or intimate self-revelation. However, a good autobiography includes both elements.

Autobiography can be a rich field of exploration for those interested in the study of one's life in detail, as they provide a vehicle for the study of the forces at work in life shape and influence the personality. To quote Joy Paul Guilford: "If life is a kind of symphony, an autobiography is written about an unfinished symphony, and gives only one rendering or interpretation" (as cited in Boring \& Lindzey, 1967, p. 169). Then, life is a sequence of personal events, of birth, school, marriage and parenthood, work, retirement, and ultimately death. When Guilford claims that life is a kind of symphony, he means to say that it has a central theme, with variations on that theme. There is a strong feature of unity about it. But its significance may appear different to each individual who listens to the symphony. In brief, autobiography is an intellectual life history, but at the same time it is illuminated by as much information about his/her personal background and inner motives as the readers are ready and able to divulge.

Indeed, the word 'autobiography' starts out like 'automobile' but it arrives at a different place. An automobile takes one somewhere; an autobiography takes one to his/her inner self. It drives straight into inner life of the autobiographer. One becomes curious about what great men, or even ordinary men, think and, in their private lives, do. In a sense, the way to write this kind of piece is to dramatize a few significant incidents that make some point about one of the reader's experiences, trying to bring the people involved to life and emphasizing elements of conflict and struggle. The autobiographer, through the book, finds a multitude of followers to share his/her inner life.

The 'self' of the autobiographer in his/her work is an essence, and for Spengemann (1980):

Without a self, one cannot write about it, but whatever one writes will be about the self it constructs. Autobiography thus becomes synonymous with 
symbolic action in any form, and the word ceases to designate a particular kind of writhing. (p. 168)

In this way, this remark may serve as a modest introduction to Burke's (1966) persistent concern with literature as a symbolic action. For instance, if we use the expression 'symbolic action' to designate the use of symbol system, he claims, "insofar as any symbol system refers to any aspect of the non-symbolic realm there is a qualitative difference between the symbol and the symbolized" (pp. 480-482). In doing so, words are symbolic because they are not the things they represent. In addition, they are also 'symbolic of' important psychological operations.

The fundamental assumption behind all these treatments of autobiography as thing in itself is that genre is more imaginative, rather than passively reportorial or a direct narrative aiming at a truthful record of the author's life, which is to say literary. In sum, whether a particular study uses autobiography as a source of information, or simply treats some literary work as an autobiography, it will adopt one of these theoretical positions biographical and imaginative which will, in turn, condition everything else the writer has to say.

\section{THE SELF IN AUTOBIOGRAPHY}

This tough self-knowledge makes Wilde watchful of himself as a performer in his play and wry about himself as a sage for the world, as someone who can rest on the results of performance. His autobiography aims not to report what the writer's life has done but to convey him through symbolic action to self-knowledge. As Spengemann's (1980) views on Thomas De Quincey's Confessions suggests the ideas that

True being is contingent upon, nor prior to, human action, the idea is implicit in the modulation of the work's representative mode from biographical metaphors that reflect the self, to fictive metaphors that express the self, to fictive metaphors that create the self they reveal. (p. 108)

That is to say, the self for which the autobiography has been imaginatively seeking lies in the autobiography itself, created in the act of searching for it.

As the self becomes identified with autobiography, it becomes a work about itself, assuming that the self exists independent of the actions of the poetic imagination. At the same time, it can be discerned through such actions. The question is whether this idea in the absolute self, and hence the traditional idea of autobiography as a genre addressed to that subject, as Spengemann (1980) claims, can "survive that is visual identification of the self with the poetic actions performed in the hope of realizing it" (p. 134).

Wilde's contemporaries liked or disliked him largely for the wrong reasons and the early twentieth century critics reached decisively against him. From the first reviews of his early poetry through to the obituaries which attempt to evaluate his life work, emphasis was placed on the beauty and wit of his style. In a letter to the editor of The Scots Observer, Wilde (1962) claims,

The pleasure one has is creating a work art is purely personal pleasure, and it is for the sake of this pleasure that one creates. The artist works with his eyes on the object. Nothing also interests him. What people are likely to say does not even occur to him. He is fascinated by what he has in hand. He is indifferent to others. I write because it gives me the greatest artistic pleasure to write. (p. 266) 


\section{Crossing the Border: International Journal of Interdisciplinary Studies}

As a successful writer, Wilde sets out to amuse and pays the price of being less than seriously. At its best, he is likely to find himself cast in the role of jester, whom no one really listens to, despite his unusual privilege of telling the truth. Yet he himself is known as prince of entertainer and his laughter can be a simple delight. His laughter, moreover, has it serious side as his first hearers often know to their cost. As his serious ideas underlying his jests becomes too apparent.

However, Wilde's serious ideas and his laughter have been misunderstood. It doesn't matter of the consciously seriousness in Salomé, where something is very obviously wrong, but of the values and insights behind his wit itself. The wit, in the eighteenth century sense of a creative, cultivated intelligence, is conspicuous. $\mathrm{He}$ stood unashamedly for aestheticism, asserting this doctrine in a series of amusing paradoxes. His paradoxes represent a specific style of epigram, that is, the association within one statement of two apparently contradictory ideas in order in order to challenge accepted conventions or to suggest new ones. Here, its satire lies in the paradox of using the conventions of specific style. For Dyson (1965), the paradox is not a problem since it is taken as a challenge that the normal morality it outrages ( $\mathrm{p}$. 139). Then, we are the more ready to write of as flippancy like Wilde in proportion as we fail to take seriously his underlying ideas. As for Juan (1967), Wilde's wit and paradox give "the introspective self with an efficient vehicle for sublimating obsessions and externalizing disproportions ... thus exorcised the irrational demons of the self" (p. 12).

Wilde (1962), it is necessary to retrace certain of his relationships, believed in the cult of beauty and became the martyr of aestheticism. His academic career at Oxford was remarkable, for he was pleased to demonstrate his academic brilliance. Such in initiatory experience took place when he left Ireland for England. The two turning-points occurred in his life, he observes, "When my father sent me to Oxford, and when society sent me to prison" (p. 469). To Wilde, who believed in the radical autonomy of the self, this was hateful stuff. He saw the self as a work of art, to be made and remade; for him, it was society that was the dreary imposition. At Oxford, he should have made himself familiar with the classics such as Plato and Aristotle. Instead, he widely read the writings of Spinoza, Goethe, Hegel, Renan, Arnold, Emerson and Baudelaire. And even at this early age of his Oxford he was a man of exceptionally wide culture.

\section{ART FOR ART'S SAKE}

To Wilde the two principal figures at Oxford he most wanted to meet were John Ruskin (1819-1900), Slade Professor of Fine Arts and author of many essays and articles on painting and architecture and Walter Pater (1839-94), a fellow of Brasenose College, Oxford, who had established himself as an authority on Aesthetics with the publication of Studies in the History of the Renaissance in 1873. At first, Wilde had no idea how opposed to each other they were. For instance, Pater who was Ruskin's disciple opposed his master without naming him and interestingly Ruskin ignored Pater's aspirations to oppose him. According to Wilde, by the time he reached Oxford, aestheticism was a familiar subject. In addition, Wellek (1966) regards Wilde who "traces the aesthetic movement from Keats and Shelley, through Ruskin and the Pre-Raphaelites, to Morris and Pater. Quotations from Goethe, Heine, Heine, Baudelaire, and Gautier buttress the argument" (p. 408). However, they both already 
preached him the doctrine of 'Art for Art's Sake' representing the search for beauty as a new morality. In a sense, while at Oxford, between 1874 and 1878, Wilde was looking for some creed or set of principles which could give shape and expression to his searching for the self, his own passionate appreciation of object, experiences or ideas whose symmetry of form, or harmony and brilliance of decoration apparently separated them form common place realities.

The dominant influence upon the more sensitive and cultivated undergraduate like Wilde was that of Ruskin. He lectured in Oxford between 1869 and 1878 and again during 1883-1884, and whose teaching was gratifying and instructive to him. Later, in a letter to Ruskin, Wilde (1962) claims,

The dearest memories of my Oxford days are my walks and talks with you, and form you I learned nothing but what was good. Who else could it be? There is in you something of prophet, if priest, and of poet, and to you the gods gave eloquence such as they have given to none other, so that your message might come to us with the fire of passion, and the marvel of music, making the deaf to hear and the blind to see. (p. 218)

This means that during his early days at Oxford, Wilde was not the follower of the individualistic aestheticism that was favoured by Pater; but he seems consciously to have imitated Ruskin's views, in other works, as what Ruskin did that art had a role in the improvement of society.

Ruskin's passion for beauty was shared by another of the older contemporary of Wilde at Oxford. It was Pater, who was destined to have an even stronger influence on the expanding intelligence of Wilde.

Wilde, obviously, had been offered two very different doctrines though both Ruskin and Pater favored beauty: for Ruskin it had been allied with good and for Pater it might have even so slight a touch of evil. For instance, Ellmann (1982) argues,

Ruskin spoke of faith; Pater spoke of mysticism, as if for him religion became bearable only when it overflowed into excess. Ruskin appealed to conscience Pater to imagination. Ruskin invoked disciplined restraint, Pater allowed for a pleasant drift. What Ruskin loathed as vice, Pater caressed as wantonness. (p. 13)

In fact, Wilde did not meet Pater in person until his third term at Oxford but during his first term the come under the spell of Pater's studies in the history of the Renaissance which he always considered it as "my golden book," and as "the book which has had such a strange influence over my life" (p. 471). Pater (1873), in a celebrated conclusion of this work, remarks,

A counted umber of pulses is given us of a variegated dramatic life. How can we see all that to be seen in them by the finest scenes? How can we pass most quickly form point to point and be present always at the focus where the greatest number of vital forces unite in their purest energy? To burn always with this hard, gem-like flame, to maintain this ecstasy to success in life... what we have to do is to be forever curiously testing new opinions and courting new impressions ... we have as interval, and then our place knows us no more. Some spend this interval in listlessness; some in high passions the wisest, in art and song ... for art comes to you professing frankly to give nothing but the highest quality to your moments as they pass, and simply for those moment's sake. (pp. 211-213) 


\section{Crossing the Border: International Journal of Interdisciplinary Studies}

In Wilde's Salomé, Salomé and Herod embrace this doctrine of art for art's sake in its purest form. Salomé burns through the passions for Jokanaan and Herod for Salomé, and most of all, through Wilde's art. Although he never absolutely shook off the influence of Ruskin, for instance, his Soul of Man under Socialism is a curious evidence of that, and even he approached Ruskin for spiritual guidance. It was plainly Pater's teaching that he found so much in conformity with his own instincts that the henceforward adopted it as his rule of life.

Apart from this, a group of painters known as the Pre-Raphaelites were adapting the ideas of Ruskin and Pater in their exploration of a style freed from the restrictions of naturalistic perspective and familiar subjects. They drew images from Celtic as well as classical mythology and presented them with a richness of detailed decoration which owed much to medieval church paintings and illuminated manuscripts.

Wilde came down from Oxford and was giving himself airs as the leader of a new movement. The period during the years between 1882 and 1888, however he wrote little to attract attention, was the second most formative epoch of his career. For, during frequent visits to Paris, he came into contact with French man of letters. Wilde, of course, was already aware of the existence of the French Decadent school, the influence of Baudelaire has reached England through Swineburne long before. Wilde's new cult was, in England, only accomplished in the eighties and the nineties; the self was at the center of his artistic pursuit.

\section{AMBIVALENT NATURE OF ART AND BEAUTY}

The main issues in aestheticism: First, to identify the unique, the nature of work of art, its mode of existence and secondly, to recognize its inescapable relation to the fundamental values of life. There are, of course, a large number of ways of dealing with the complex relationship between art and life. But there are certain important aspects of the relationship which Wilde saw very clearly are seen today hardly at all. In a letter known as De Profundis to Lord Alfred Douglas, Wilde (1905) calls of himself as a "man who stood in symbolic relations to the art and culture of his age" (p. 77). Also, he claims himself as saying, "I made art a philosophy and philosophy an art ... I treated art as the supreme reality and life as a mere mode of fiction; I awoke the imagination of my country so that it created myth and legend around me" (p. 77). He, thus, creates this difficulty for challenge and uses one of terminologies. Art is to do with the ambition to make life itself a shaped and satisfying whole. As Wilde (1992) asserts in this way, "Emotion for the sake of emotion is the aim of art, and emotion for the sake of action is the aim of life" (p. 978). This is how Wilde considers art to be.

Wilde views that art is more ordered than life is reinforced, is more permanent that comes as near to the immortal and immutable as anything in a turning world over will. This insight came into him form Keats' Odes, meditated through the PreRaphaelite sensibility and already decisively diverted towards Pater. In Keats, the insight is balanced in the view that art gets permanence only at the expense of organic life, for instance, the Grecian Urn, though a vision of fullness, is also 'cold pastoral' the nightingale's song is not only symbol but fancy -

Adieu! The fancy cannot cheat so well

As she is famed to do, declining elf. (Keats, 1977, p. 73)

The ambivalence of the odes is richly moving as well as inseparable from their great- 
ness. Wilde (1992) also concentrates between art and life, and makes the permanence of art, distorts the balance which Keats has kept and sacrificed truth as well as complexity in doing so as the following lines indicate:.

There is no such thing as a moral or an immoral book,

Books are well written, or badly written. That is all. (p. 17)

A work of art is useless as a flower is useless. A flower blossoms for

Its own joy. We gave a moment of joy by looking at it. (p. 978)

$\mathrm{Al}$ art is immoral. (p. 978)

The above quotations indicate his altitude towards art, which is the basis for his science of beautiful. He means that art is primarily concerned with perfection. It is therefore said to be immoral by those who prefer ugly to beauty, in other words, an absolute distinction between social taboos and the artist's insights. Similarly, artist in not a preacher but a maker, and that what he makes will be entirely useless for exhortation and propaganda.

Wilde chose, however, to call this 'aesthetic' rather than 'moral' handing the latter word over to those most fond of using it. In this connection, Dyson (1951) declares,

The abandonment of the word 'moral' was meant to shock, but not to be taken at face value. Wilde's whole wit is a series of shocks to normal responses intended to offer the delight of emancipation culmination in the delight of extended insight. (p. 141)

At the literal level, Wilde's irony is mistaken for flippancy. The trick to make this error is precisely the technique, upon which the irony depends, at the same time, falling upon this trick is, thus, a failure of intelligence in reading.

The theory of art resides intently on the terms 'art' and 'beauty.' Beauty is something very pure and very different forms everything else. Regarding this, Wilde (1992) claims, "Beauty is the symbol of symbol. Beauty reveals everything, because it expresses nothing" (p. 969) and "all art is useless" (p. 17). Art is more organized than life, however; he believes that art is more beautiful than life. The supreme secret of beauty is from which in men manifests itself as conduct in nature as harmony, in art as style. He rejects the Romantic reverence for Nature. Nature, he asserts, is lamentable crude and unshaped, for form being the source of moral enlightenment or poetic sensibility, Wilde (1992) observes, "What Art really reveals to us is Nature's lack of design her curious crudities, her extraordinary monotony, her absolutely unfinished condition" (p. 909). Man and nature, thus, are always changing. For instance, the sunset no sooner appears than it starts to face; fade the colours alter as we watch them. Even human being alters in the course of time; a child grows up as youth and ultimately old or death. Only in art is the beauty which natural scenery and conduct no more than hint at given shape, significance, and the prospect of permanence. Only the artist can give to the beauty the sees a form that moves it towards its own ideal.

Wilde published Intentions (1891), a collection of dialogues and essays. He explains his artistic principles as the importance of Art for Art's Sake rather than as a vehicle for moral instruction. According to him, the presentation of Beauty and wit is more important than naturalism as the artist's proper concern. He developed this idea, while defending The Picture of Dorian Gray and Salomé against accusation of decadence and obscenity. He (1962) argues, "An artist, sir, has no ethical sympathies at all. Virtue and weakness are to him simply what the colours in his palette are to 


\section{Crossing the Border: International Journal of Interdisciplinary Studies}

the painter" (p.81). Even in his later life, paying heavy price for putting his principles into practice, Wilde realizes that he has become the scapegoat merely because he supports for aestheticism and because he worships for beauty and art for art's sake.

At the same time, Wilde (1905) feels happy, however, when he considers that "everything about my tragedy has been hideous, mean, repellent, lacking in style" (p. 115). In addition, he observes that "the one disgraceful, unpardonable, and to all time contemptible action of my life was to allow myself to appeal to society for help and protection" (p. 117). Wilde, in this way, insists upon the artist's necessary freedom to seek experiences beyond the boundaries permitted by society. One can then argue that he is not a martyr of art and the aesthete life at all, unless one deliberately confuses art with sexual derivation. Wellek (1966), in this regard, claims, "The Philistine enemies of the artists welcomed this confusion, but the cause for the genuine freedom of the artist was hurt rather than helped by Wilde's sordid tragedy" (p. 408). Here, Wilde has unknowingly created in his life a perfect classical tragedy. In this regard, Frank Harris has once remarked to Herbert Gorman as he explains, "Oscar Wilde's greatest play was own life. It was a five act tragedy with Greek implications and he was its most ardent spectator (as cited in Wilde, 1992, p. 5). With head holding high, he has contributed to his own downfall, and forced his life into parabolic shape which remains his greatest artistic creation: The Tragedy of Oscar Wilde.

A consequence of this is recognition that it is the tragedian-author, the thinker of the tragic thought and is also the real tragic-hero. The author of tragedy is not the protagonist of his particular plot of fable, or the reader or catharsis-consumer. We feel for the tragic hero, yet we do not feel for him as we do for a man suffering in real life, where events are isolated and unpredictable, and where suffering happens in front of our eyes instead of being merely enacted. The tragedies of life have less shape than those of art, and more poignancy where grief and incredulity mingle with the classical responses of pity and fear.

After having considered all these, Wilde completed his aesthetic, noticing that our major pleasure in Salomé comes from its form, which paradoxically consoles as almost in proportion to the intensity of the grief being portrayed: First, he allows King Herod to yield to sensual delectation as he watches Salomé dance, to jealousy as he watches her kissing of dead Jokannaan, and to outraged conscience as he commands the soldiers to kill her. The language of grief in Salomé, for Wilde (1992) is "the birth of passion is also the death of pain" (p. 991). Thus, if the play expresses grief, it also expresses an act, a composition, an expression, a making. Secondly, Salomé, an autobiographical piece written in the dramatic mode, is the expression of melancholic self-consciousness; he has begun to deal with the problem of imagining the self that occurs together with awareness of functions of text. As a result, writing any kind of autobiography assumes both one's own importance and the appropriateness of writing about one's experiences. Then, each person examines carefully the events in the development of the self.

\section{CONCLUSION}

Salomé invites the conflicting interpretations that have precedence in Wilde's divided selves. Consequently, he has not made the slightest attempt to see his life as unity and to describe it in term of spiritual growth. In fact, the play is not an account of the author's life at all; it is no more than a string of reflections, recollections and 


\section{ART AND AUTOBIOGRAPHY}

anecdotes. Moreover, a number of the anecdotes hardly repay the reader's attention. He does not draw full-length portraits, but characters always existing in their relation to him; yet his telling details of anecdote can be the key to his personality and his art.

This means that the meaning of the work lies outside of it, in some moral proposition which it merely illustrates to locate reality in human action rather than in some ideal realm to which actions point. In Salomé, Wilde performs symbolic actions in the hope of identifying an unconditional ground behind the confliction elements of his conditioned life; in other words, the autobiography becomes the form of literature which is cornered with the self-revelation of the authors. As the autobiographers write about their self, they come across certain difficulties and dangers in the way.

In conclusion, the greatness of an autobiography such as Wilde's Salomé does not depend upon the greatness of the writer but upon the literary skill with which the personality of the writer has been revealed to us. The autobiographer opens before the reader the innermost recesses of his heart. For instance, in Salomé, all the arts of expression are gathered together, and have offered Wilde an opportunity to express his vision of live as self-expression. The urge to express one's own contradictions in the form of a book is inherent in human nature. When it finds expression in words, it takes the form of autobiography.

\section{REFERENCES}

Boring, E. G. \& Lindzey, G. (1967). A History of psychology in autobiography. Vols. 5. New York: Appleton-Century-Crofts.

Burke, K. (1966). Language as symbolic action. Berkeley \& Los Angeles: University of California Press.

Collier's Encyclopedia. (1957). Vols. 20. New York: PF Collier.

Cuddon, J.A. (1991). The penguin dictionary of literary terms and literary theory. London: Penguin Books.

Dyson, A. (1965). The crazy fabric. London: Macmillan and Co. Ltd. \& New York: St. Martian's Press.

Dyson, A. (1951). The crazy fabric. London. MacMillan and Co. Ltd. and New York: Hendricks House, Inc.

Ellmann, R. (1982). Four Dubliners. London: Cape

Juan, E. S. (1967). Art of Oscar Wilde. Princeton, N.J.: Princeton University Press.

Keats, John. (1977). "Ode to Nightingale" in A Pageant of Poems. Calcutta \& New Delhi: Orient Longman.

Pater, Walter. (1873). “Conclusion." Studies in the History of the Renaissance. London: Macmillan.

Rogers, C.R. (1967). A History of Psychology in Autobiography. New York: Delacorte Press.

Spengemann, W. C. (1980). The forms of autobiography. New Haven and London:

Yale University Press.

Wellek, R. (1966). A history of modern criticism 1750-1950. London: Jonathan Cape.

Wilde, Oscar. (1905). De Profundis. London: Methuen.

Wilde, Oscar. (1962). The letters of Oscar Wilde. London: Butler \& Tanner Ltd.

Wilde, Oscar. (1992). The Complete Works. London and Glasgow: Collins. 


\section{Crossing the Border: International Journal of Interdisciplinary Studies}

\section{ABOUT THE AUTHOR}

Dr. Min Pun has been working as Associate Professor of English at Tribhuvan University, Prithvi Narayan Campus, Pokhara for more than two decades. He has received his Ph.D. from Tribhuvan University and had been a Visiting Researcher at the University of Tokyo, Japan from 2003 to 2005. He has also published research articles on topics related to English literature and Nepali literature in English in national and international journals. Email:minpun@pncampus.edu.np 